\title{
Guest editorial - Policies and practices in action to address soil erosion
}

\author{
Clara Lefevre ${ }^{1}$, Megan Balks ${ }^{2}$, Generose Nziguheba ${ }^{3}$, and Rosa Poch ${ }^{4}$ \\ ${ }^{1}$ Global Soil Partnership Secretariat, Food and Agriculture Organisation of the United \\ Nations (GSP/FAO) \\ ${ }^{2}$ University of Waikato, \\ ${ }^{3}$ International Institute of Tropical Agriculture, Intergovernmental Technical Panel on Soils \\ ${ }^{4}$ University of Lleida
}

June 11, 2021

\begin{abstract}
This special issue is the second published after the Global Symposium on Soil Erosion (GSER, 15-17 May 2019, Rome, Italy) and includes contributions dealing with the 2nd theme of the GSER: Policies and practices in action to address soil erosion. While there is a good scientific understanding of the physical measures that can be used to prevent or mitigate soil erosion, the main constraints to progress often relate to policy development and or implementation as well as socio-economic aspects that provide limitations to implementation of sustainable soil management (SSM) practices including those directed to control erosion. There are no right or wrong answers to which policy or approach is most effective. Some combination of approaches needs to be adopted that work in the particular political, cultural, and socio-economic environment under consideration. The papers included in this special issue provide examples, from the national to local level, that could be adapted, or used, to improve uptake and implementation of SSM practices to prevent or reduce soil erosion. Regardless of what policy or plan is developed there has to be effective interaction with the local farmers and land managers as they are key to implementing any actions that will make a practical difference on the ground. Effective policies cannot be developed or implemented without bringing the land managers "on board" and the needs and limitations of the local farmers must be thoroughly understood and considered in any policy or plan development.
\end{abstract}

\section{Hosted file}

LDD Editorial_clean_020421.pdf available at https://authorea.com/users/419204/articles/ 525755-guest-editorial-policies-and-practices-in-action-to-address-soil-erosion 